فاعلية تعض المطهرات الكيهاوية فى بعض التدوى الفيروسية اللداوجن

$$
\begin{aligned}
& \text { r - فيروس السبسيلو } \\
& \text { ب.أى· فولفنج · ع· اسماعيل ، ه• جيسلر } \\
& \text { اللاخص العربى }
\end{aligned}
$$

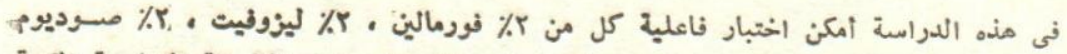

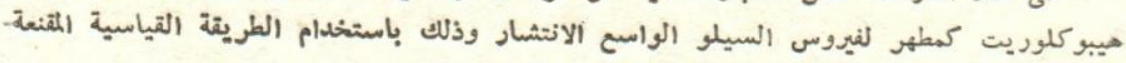

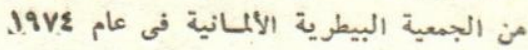$$
\text { وآمكن تلخيص النتائج فى الآتى : }
$$$$
1 \text { ـ أبدى فيروس السيلو مقاومة كبية لثأثير المطهرات - }
$$

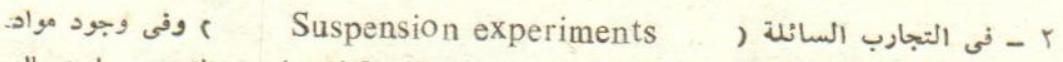

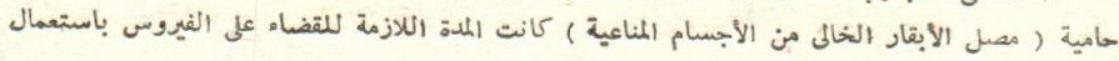

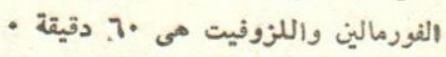

r - لم يثبت الصوديوم هيبوكلوريت أى فاعلية فى التضاء على الفيروس مع وجود المسادة.

$$
\text { الجامية حتى ولو بعد •rا لو دقيقة • }
$$

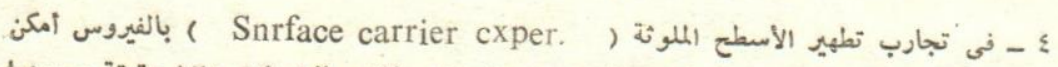

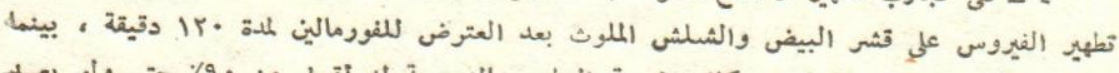

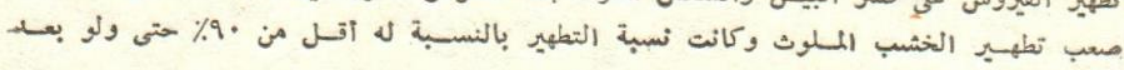


From the institute for Poultry Diseases Justus Liebig-University, Giessen

Head: Prof. Dr. H. Geissler

From the Dept. Medicine and Infectious diseases

Faculty of Vet. Medicine, Zagazig University,

Head Prof. Dr. H. Gahrib,

\title{
ANTIVIRAL ACTIVITY OF SOME CHEMICAL DISINFECTANTS AGAINST SOME POULTRY PATHOGENIC VIRUSES
}

\author{
II. CELO-VIRUSS.
}

Received at . / / 1976

(With 5 tables one figure)

By

P.E. Woelfing, A. Ismail ${ }^{*}$ and $\mathrm{H}$, Geissler

\section{SUMMARY}

In the course of this investigation, the antiviral activity of $2 \%$ formalin, $2 \%$ Lysovet ${ }^{\mathrm{R} J}$-forte and $2 \%$ sodium hypochlorite was studied on the wide host range CELO-virus. Experimental procedure used, was that discribed by GVS (1974).

Results obtained could be summerised in the following :

1. CELO-virus showed comparativly greater resistance to disinfection.

2. In suspension experiments $2 \%$ formalin and $2 \%$ Lysovet ${ }^{\mathrm{R}} \mathrm{J}$-forte needed at least $60 \mathrm{~min}$. exposure to inactivate CELO-virus in the piesence of protecting substance.

3. $2 \%$ Sodium hypochlorite failed to show any disinfecting actiity against CELO-virus in suspension in presence of protecting substance ever after $120 \mathrm{~min}$ exposure.

4. In CELO-carrier surface experiments with $2 \%$ formalin an effective disinfection could be obtained in case of gauze and egg shell carriers only after $120 \mathrm{~min}$. exposure. Wood-carrier showed difficulty to disinfection. $<90 \%$ disinfection success was obtained even after $120 \mathrm{~min}$. exposuré.

\section{INTRODUCTION}

Chicken Embryo Lethal Orphan (CELO-Viruses), which were identified as avian adeno viruses have a wide host range. They were reported in quail (Du BosE et al 1958, Du Bose and GRUMBLES 1959), in chickens (WOERNLE and BRUNNER 1963, ERDOS 1964, KRAUSS 1965, ISMAIL

R : Fa. Schulke and Mayer (W. Germany).

- Faculty of Vet. Menicine Zegazig University, Egypt. 
1966, AHMED et al 1968 a.b and 1969), in ducks (GRENEL 1966, AHMED et al 1969 AHMED 1971 b), in geese (KALETA 1969 and CSONTOS: 1967), in turkeys (AHMED 1971 a.b 1973). CELO-viruses might be present in other spieces of birds not yet investigated GREUEL (1966).

Numerous investigations had revealed that there were variations in pathogenicity among CELO-Viruses for poultry. They caused motsly inapperant or latent infection in chicken (YATES and FRY 1957, YATES et al 1960, CHOMIAK et al 1961, BURKE et al 1965 and COOK 1968). Due to this latency the vius was at one time thought to be the cause of lymphomatosis in chicken (FONTES et al 1958, SHARPLESS et al 1958 and BURMESTER et al 1960)., then it was identified as avian adenovirus (BURMESTER et al 1960, SHARPLESS and JUNGHERR 1961 and SHARPLESS 1962).

In chickens CELO-infections were sometimes associated with mild respiratory manifestation, conjunctivitis, diarrhea, low egg production and nervous manifestation (WOERNI E and BRUNNER 1963,KAWAMURA et al 1963, 1964, ISMAIL 1966 and AHMED and EL SISI 1969). Strains of CELO-viruses. were also isolated from appearently healthy chickens (CLEMMER 1964, 1965, KHANNA 1964). In some experimental trials CELO infections passed symptomless (BURKE et al 1959, KOHN 1962, - and MONREAL 1968).

On the other hand certain CELO-virus strains were responsible for a specific disease in quail "Quail Bronchitis" (DU BOSE et al 1958 and DU BOSE and GRUMBLES 1959).

CELO-infections could not be neglected as a complicating factor in the course of some diseases of poultry i.e. mycoplasmosis and infectious bronchitis (IB) (MONREAL and AHMED 1963), ISMAIL 1966, GESSLER 1966, MONREAL 1966, 1968 and AWAD et al 1973). GESSLER (1966) is of the openion that a corrilation existed between hygenic condition and the appearance of CELO and infectious bronchitis antibodies in chicken sera.

The aim of this study was to test the antiviral activity of $2 \%$ formalin,

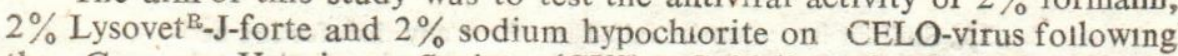
the German Veterinary Sociaty (GVS) "Guidelines for testing chemical disinfectants (1974).

\section{MATERIALS and METHODS}

\section{1: Virus-strain.}

CELO-PHELIPS Strain in 13 th egg passage was used as model for non enveloped, lipid-free viruses.

\section{2: Disinfectant:}

Formalin $2 \%$, lysovert ${ }^{\mathrm{R}}$ - $\mathrm{J}$ forte $2 \%$ and sodium hypochlorite $2 \%$ in distelled water.

Assiut. Vet. Med. J. Vol. 4 No. 7 (1977). 


\section{3: Test system:}

9 to 11 days living embryos were used in this study. Embryonated eggs were obtained, from poultry diseases Institut's SPF-Farm (Giessen, W.

Germany). Numebr of embryos used in these experiments were included in the tables.

\section{4: Cattle serum:}

$40 \%$ inactivated antibodies free sterile cattel serum with $6 \%$ protein was used as protecting substance in this study.

2. Methods:

The following procedures were described in details ISMAIL et al (1975).

A. prelminary testing:

2.1: $\mathrm{p}^{\mathrm{H}}$-value $: \mathrm{PH}$. of disinfectant in applicable concentration as well as disinfectant virus serum mixture were determined by electrical PH-meter.

2.2 Determination of disinfectant toxicity on test system.

2.3 Viricidal activity of disinfectant in suspension.

2.4 Viricidal activity of disinfectant in suspension in presence of protecting substance (cattle serum).

B. Main testing:

2.5 CELO-carrier surfaces: gauze, egg shell and wood.

2.6 Titer reduction.

\subsection{Virus assays:}

Demonstration of viable (multiplication cabaple) virus was Judged by the pathological manifestation induced in incoulated chicken embryos. These included death, petechial hemmorrhage especially on extremites, dwarfing, liver necrosis and sometimes defective feathering were observed. Titer calculation was done after SPERMAN \& KARBER (1973).

\section{RESULTS}

1. Virus assay:

phelips strain-CELO- virus was propagated in chicken embryos. Two successive passages were needed to reach $10^{7.5} \mathrm{ELD}_{50} 0.1 \mathrm{ml}$. (concentration required for test virus GVS-1974).

2. Disinfectant toxicity to test system and $\mathrm{PH}$ value of disinfectant:

Results of disinfectant toxcicity to test system and $\mathrm{p}^{\mathrm{H}}$ value are summerised in table (1). 
TABLE 1. pH value of disinfectant and its toxicity to test system

\begin{tabular}{|c|c|c|c|c|c|c|c|c|}
\hline \multirow{2}{*}{ Disinfectant } & \multirow{2}{*}{ 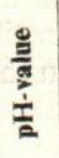 } & \multicolumn{5}{|c|}{ observation period in days } & & \\
\hline & & 1 & 2 & 3 & 4 & 5 & 6 & Coatrot: \\
\hline Formalin ... $(0.2 \%)^{2} 2 \%$ & 3.7 & $0 ! 5^{*}$ & $0 / 5$ & $0 / 5$ & $0 / 5$ & $0 / 5$ & $0 / 5$ & $0 / 5$ \\
\hline Lysovet . . . $(0.2 \%)^{2} 2 \%$ & 2.6 & 0.5 & $0 / 5$ & $0 / 5$ & $0 / 5$ & $0 / 5$ & $0 / 5$ & $0 / 5$ \\
\hline Sodium hypochlorite $(0.2 \%)^{\mathrm{a} 2} \%$ & 8.7 & $0 / 5$ & $0 / 5$ & $0 / 5$ & $0 / 5$ & $0 / 5$ & $0 / 5$ & $0 / 5$ a \\
\hline
\end{tabular}

* embfyos showing lesions/ embroys inoculated

a) end concentration for inoculation (GVS - 1974).

From the results in (table 1) it was proved that $2 \%$, formalin, $2 \%$ lysovet $^{\mathbb{R}}$. and $2 \%$ sodium hypochlorite has no toxic effect on test system.

3. Suspension experiments:

Disinfecting activity of $2 \%$ formalin, $2 \%$ lysovert $^{\mathrm{P}}-\mathrm{J}$ forte and $2 \%$ sodium hypochlorite against CELO-vorus in presence and absence of Organic matter protecting substance) were determined in suspension trials. Results obtained are summerised in tables $(2,3 \& 4)$ respectively.

TABLE 2. Effect of $2 \%$ formalin on CELO virus in suspension

in presence of serum exposure $/ \mathrm{min}$

in absence of serum exposure/mia

\begin{tabular}{|c|c|c|c|c|c|c|c|c|c|c|}
\hline dil & $\mathrm{pH}$ & 15 & 30 & 60 & $\begin{array}{c}\text { virus } \\
\text { cont } .\end{array}$ & pH & 15 & 30 & 60 & $\begin{array}{l}\text { virus } \\
\text { cont }\end{array}$ \\
\hline $10^{4}$ & & $0 / 5^{*}$ & $0 / 4$ & $0 / 5$ & $5 / 5$ & & $0 / 5$ & $0 / 5$ & $0 / 5$ & $5 / 5$ \\
\hline $10^{3}$ & 7.05 & $3 / 5$ & $2 / 5$ & $0 / 5$ & $5 / 5$ & 6.7 & $1 / 5$ & $0 / 3$ & $0 / 4$ & $5 / 5$ \\
\hline $10^{2}$ & & $5 / 5$ & $3 / 5$ & $0 / 5$ & $5 / 5$ & & $3 / 5$ & $1 / 5$ & $0 / 5$ & $5 / 5$ \\
\hline tier reduction & & $10^{4.6}$ & $\left|10^{5}\right\rangle$ & $10^{6.5}$ & & & $10^{5.2}$ & $10^{6.2}$ & $>10^{6.5}$ & \\
\hline disinurscess . & & $<99$. & $.9 \%$ & $99.9 \%$ & & & $<99.9 \%$ & & $>99.9 \%$ & \\
\hline
\end{tabular}

From table 2 it is appearent that $2 \%$ formalin inactivated CELO-virus only after $60 \mathrm{~min}$. exposure even in absence of protecting substance.

* embroys with CLO lesions embryos inooulated.

Assiut. Vet. Med. J. Vol. 4 No. 7 (1977). 
TABLE 3. Effect o: $2 \%$ Lysovet $\mathbf{J}$-forte on CELO-virus is suspension.

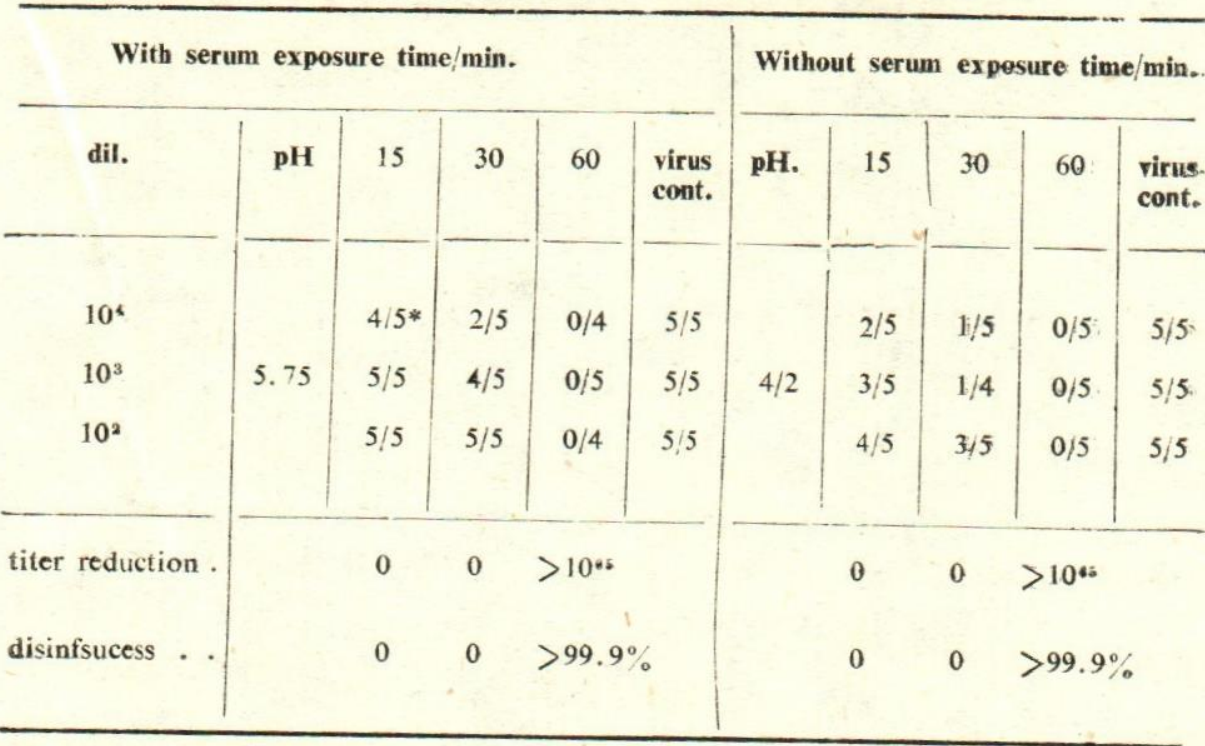

Table (3) showed that $2 \%$ lysovet could inactivate CELO-virus after 60 mint exposure even in presence of protceting subtance.

TABLE 4. Effect of $2 \%$ sodium hypochlorite on CELO-Virus in suspension

\begin{tabular}{|c|c|c|c|c|c|c|c|c|c|c|c|c|}
\hline \multicolumn{7}{|c|}{ With serum exposure time/min. } & \multicolumn{6}{|c|}{ Without serum exposure time/mix } \\
\hline dit. & pH. & 15 & 30 & 60 & 120 & $\begin{array}{l}\text { virus } \\
\text { cont. }\end{array}$ & pH. & 15 & 30 & 60 & 120 & $\begin{array}{l}\text { virus } \\
\text { cont. }\end{array}$ \\
\hline $10^{4}$ & . & $4 / 4^{*}$ & $5 / 5$ & $2 / 5$ & $2 / 5$ & $5 / 5$ & & $5 / 5$ & $5 / 5$ & $0 / 4$ & $0 / 5$ & $5 / 5$ \\
\hline $10^{3}$ & 10.5 & $5 / 5$ & $5 / 5$ & $3 / 4$ & $2 / 5$ & $5 / 5$ & $9 / 7$ & $4 / 4$ & $4 / 5$ & $0 / 5$ & $0 / 5$ & $5 / 5$ \\
\hline $10^{2}$ & & $5 / 5$ & $5 / 5$ & $4 / 5$ & $4 / 5$ & $5 / 5$ & & $5 / 5$ & $4 / 4$ & $0 / 5$ & $0 / 5$ & $5 / 5$ \\
\hline titer reduction & & 0 & 0 & 0 & 0 & 0 & & 0 & 0 & $>10^{06}$ & $<10^{46}$ & \\
\hline disinfsucess & & $\theta$ & 0 & 0 & 0 & 0 & & 0 & 0 & $>99$ & $9 \%$ & \\
\hline
\end{tabular}

$2 \%$ Sodit $m$ hypechlorite failed to show any activity against CELO- virus in presence of cattle serum even after $120 \mathrm{~min}$. exposure. In absence of protecting subtance, $60 \mathrm{~min}$. were sufficient to inactivate the same virus.

Assiut. Vet. Med. J. Vol. 4 No., 7 (1977). 


\section{Fig. 1}

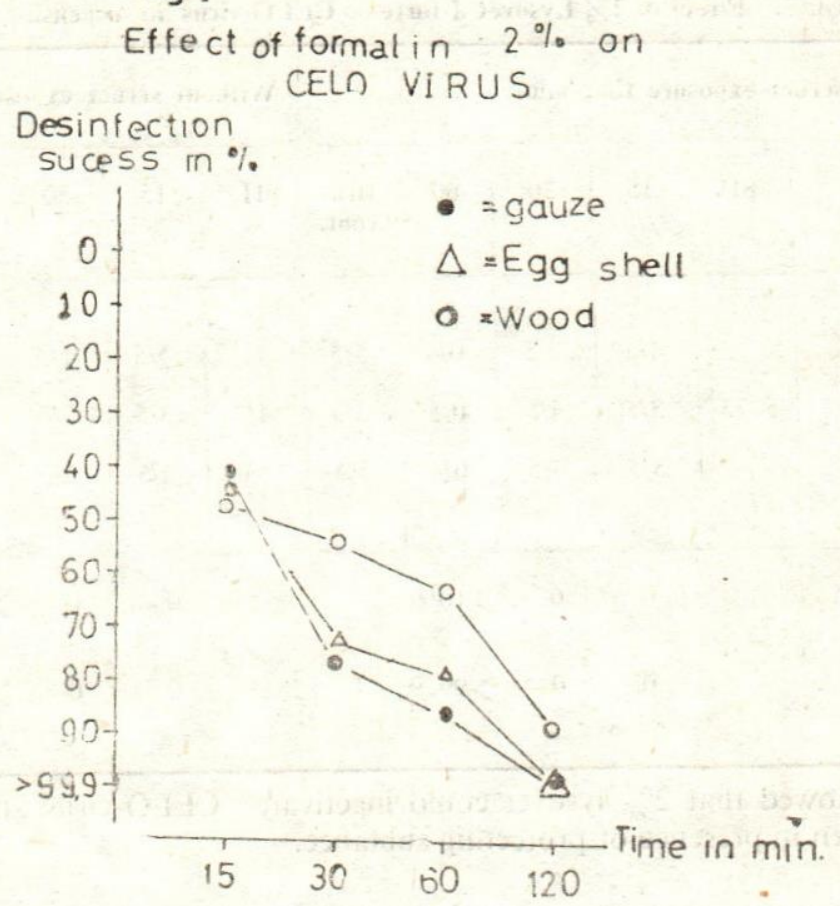

4. CELO-carrier surfaces experiments:

From economic point of view formalin was chosen for such experiments. Results of two separate trials (GVS 1974) are summerised in tabel (5

TABLE 5. Effect of $2 \%$ formalin on CELO-carrier surfaces

\begin{tabular}{|c|c|c|c|c|c|c|c|c|c|c|}
\hline \multirow{3}{*}{$\begin{array}{l}\text { Carrier } \\
\text { surface }\end{array}$} & \multicolumn{4}{|c|}{1 st trial } & \multirow{3}{*}{$\begin{array}{l}\text { virus } \\
\text { cont. }\end{array}$} & \multicolumn{4}{|c|}{$2 n d$ trial } & \multirow{3}{*}{$\begin{array}{l}\text { virus } \\
\text { cont. }\end{array}$} \\
\hline & \multicolumn{4}{|c|}{ exposure/min. } & & \multicolumn{4}{|c|}{ exposure/min. } & \\
\hline & 15 & 30 & 60 & 120 & & 15 & 30 & 60 & 120 & \\
\hline Gauze. . & $15 / 37$ & $9 / 40$ & $7 / 38$ & $0 / 38$ & $10^{7.1}$ & $17 / 39$ & $9 / 39$ & $4 / 40$ & $0 / 40$ & $10^{7 \cdot 1}$ \\
\hline Disinfsucess & $59.5 \%$ & $77.5 \%$ & $81.5 \%$ & $>99.9 \%$ & - & $56.5 \%$ & $76.4 \%$ & $90.1 \%$ & $>99.9 \%$ & - \\
\hline Egg shell . & $18 / 38$ & $11 / 38$ & $8 / 38$ & 0.37 & $10^{7.3}$ & $16 / 40$ & $9 / 40$ & $8 / 40$ & $0 / 40$ & $10^{7 . x}$ \\
\hline Disinfsucess & $47.3 \%$ & $71.1 \%$ & $79 \%$ & $>99.9 \%$ & - & $60 \%$ & 77.5 & $80 \%$ & $>99.9 \%$ & - \\
\hline Wood... & $23 / 40 /$ & $17 / 40$ & $14 / 40$ & $6 / 40$ & $10 / 6 \cdot 9$ & $12 / 38$ & $19 / 38$ & $16 / 40$ & $4 / 38$ & $10^{6.8}$ \\
\hline Disinfsucess & $42.5 \%$ & $57.5 \%$ & $65 \%$ & $85 \%$ & - & $44.7 \%$ & $50 \%$ & $60 \%$ & $89 \%$ & - \\
\hline
\end{tabular}

+ Embroys with CELO - lesions / Embroys inoculated

Assiut. Vet. Med. J. Vol, 4 No. 7 (1977). 
In two trials CELO- carrier surfaces were subjected to disinfection with $2 \%$ formalin. Gauze and egg shell carriers could be disinfected sucessfully after $12 \mathrm{O}$ min. exposure. On the other hand wood showed difficulty to disinfect. It remained in both trials under $90 \%$ A better look could be seen in figure (1).

\section{DISCUSSION}

Intensive poultry breeding to obtain optimal production is now the interest of veterinarians. In this breeding system high productive birds are easily desturbed by specific and nonspecific noxiousness. Therefor the problem of infections control appears in fore-ground. From this stand point of view, desinfection gained more interest in comparison with older times (SCHLIESSER $1974 \mathrm{a} . \mathrm{b}$ ) as tool in infection control.

The importance of avian adenoviruses was not only dut to their preliminary pathogenicity which is seldom, but also due to the complicating role of such viruses in other infections (ISMAIL 1966, GESSLER 1966, MONREAL 1966, 1968 and AHMED 1971) Beside this Gessler (1966) assumed that a relationsip was present between hygenic condition of a flock and the appearance of CELO and infectiuos bronchitis antibodies in poultry.

Results obtained in this study reveald that $2 \%$ formalin and $2 \%$ lysovet $\mathrm{J}$ forte could inactivate CELO- virus after $60 \mathrm{~min}$. exposure in the presence of protedting substances. $2 \%$ Sodium chypoc hlorite inactivated -CELO virus after $60 \mathrm{~min}$ : only in absence of protecting substances. It failed inactivate CELO- virus even after 120 minexposure in presence of inactivated antibodies free sterijle cattle serum at $20-20^{\circ} \mathrm{c}$. Similar viricidal activites against CELO- VIRUS were obtained by MAHNEL (1974). He could obtain disinfection effect with jodophore and aldehydes while cholorinated compounds were of limited values in suspension experiments. OXFORD \& POTTER (1969) obtained complete inactivation of avian adeno type 1 with formalin $0.004 \%$ after 24 hours exposure at $35-36 \mathrm{C}^{\circ}$ but not at $4 \mathrm{C}^{\circ} \mathrm{E}$ even after 14 days exposure using the same concentration. PETEK et al (1963) a, b) could inactivate CELO- Virus in $30 \mathrm{~min}$., when a mixture from 7 parts ethyl alcohol $95 \%$ and 1 part tencture iodine was used. They failed to obtain inactivation effect of the same virus with phenol $2 \%$, ethyle alchol $50 \%$ after 24 hours exposure.

From this investigation and other results obtained with Newcastle disease virus ISMAIL et al (1975) it appeared that CELO-virus was more defficult to disinfect. This conclusion agreed with (MAHNEL 1974\& GEISSLER 1974), where lipid free viruses showed great resistance to desinfection.

Desinfection of CELO-carrier surfaces were carried out in two trials (GVS 1974). $2 \%$ Formalin proved effective for ganze and egg-shell- carrier, deinfection occured only after $120 \mathrm{~min}$. exposure. $\mathrm{On}$ the other hand wood $c_{\text {arrie }}$ showed giate dificulty to disiafection as the disinfection sucess 
was under $90 \%$ even after $120 \mathrm{~min}$. exposure. This was better demonstrated in (Figure 1 and Table 5).

Results of CELO- virus carrier experiments showed no deviation from that obtained in Newcastle - carrier experiments, in that wcod was always more dificult to desinfect than gauze and egg shell carric $r$ surfaces ISMAIL et al (1976).

\section{REFERENCES}

Ahmed, A.A.S., M.A.El-Sisi, K.H. Abbasi \& M.S.Saber (1968 a). A preliminary serological investigation of some respiratory infections of poultry in Egypt. VIII. Ann. Arab. Vet. Congr. Cairo, abst. No. 51. p. 61 .

Abmed, A.A.S., M.S. Saber, M.A. El-Sisi, I.M. Reda \& K.H. Abbasi (1968 b). Further studies on respiratory infections of poultry in Egypt. Jour. Vet. Sci.(UAR), 5, 85-104. Abmed, A.S.S., \& M.A. El-Sisi (1969). CELO virus infection in chickens. Clinical and
serological response to experimental and accidental infection. Avian Dis 13, 709-720.

Ahmed, A.A.S., M.A. El-Sisi \& M.S. Saber (1969). Ein Beitrag zur Epizootologic einer adeno-ahnlichen Virus (CELO) Infektion beim Geflugel in Agypten. Tierarztl' Umschau 24, 111-115.

Ahmed, A.A.S., (1971). CELO-Virusinfektion bei Puten (Kurze Mitteilung). Berl. Munch: Tieraszt1. Wschr. 84, 211-213.

Ahmed, A.A.S., (1971 b). Die Adenovirusinfektionen beim Geflugel: Habil.Schrift. Munchen.

Awad, F.1., A.A. Bassiouni, M.A. El-Sisi \& Y.I. Youssef (1973). Clinical and serological. response of turkey poults to artificial infection with avian adeno-virus type I (CELO). Egypt. Jour. Vet. Sci. 10, 65-74.

Bwrke, C.N., R.E. Luginbuhl \& C.F. Helmboldt (1965). The isolation of a latent adeno-like virus from chicken kidney cell culture. Avian Dis 9, 31-43.

Burmester- B.R., G.R. Sharpless, \& A.K. Foutes (1960). Virus isolated from avian lymphomas unrelated to lymphomatosis virus. Jour. Nati. Cancer Inst. 24, 1443-1447.

Chomiak, T.W., R.E. Luginbuhl \& C.F. Helmboldt (1961). Tissue culture propagation and pathology of a CELO-virus. Avian Dis 5, 313-320.

Clemmer, D.I., (1964). Characterization of agents isolated from market chickens in a quest for enteric viruses. Jour. Infect. Dis. 114, 386-400.

Clemmer, D.I., (1965). Experimental enteric infection of chickens with an avian adenovirus (strais 93). Proc. Soc. Exper. Biol. \& Med. N.Y. 118, 943-948,

Cook, J.K.A. (1968). Isolation of CELO virus from fetile chicken eggs. Vet. Rec. 82, 294.

Csontos, L. (1967). Isolation of adenoviruses from geese. Preliminary report. Acta vet., Hung. 17, 217-219.

Du Bose, R.T., L.C. Grumbles \& A.I. Flowers (1958). The isolation of a nonbacterial agent from quail with a respiratory diseases. Poult. Sci. 37, 654-658.

Bu Bose, R.T. \& L.C. Grumbles (1959). The relationship between quail bronchitis virus and chicken embryo lethal orphan virus. Avian Dis 3, 321-344.

Erdos,A.M.,(1964). Isolation von chloroformresistentem "Orphan" Virus aus dem Darmtrakt des gefiugels. Ing. Diss. Hannover.

Assiut. Vet. Med, J. Vol. 4 No. 7 (1977). 
Fut:, A.K., B.R. B 1:msster, W.G. Walter \& P.E. Iseler (1958). Growth in tissue cuiture of cyto sthogzaic agent from strain of viras which produces avian lymphomatosis. Proc. Soc. Exper. Biol \& Med N.Y. 97, 854857.

GVS-Guidelines (1974), for testing chemical disinfectants.

Geissler, H. (1974). Zur Desinfektion in Geflugelentensivhaltungen. Prakt. Tierarzt. $55,556-560$.

Gessler, K. (1966). Ein Beitrag zur Epizootologie der CELO-Virus-Infektion der Huhner. Ing. Diss. Giessen.

Greuel, E. (1966). Die CELO-Virus-Infektion. Dtsch. tierarztl. Wschr. 73, 5-10.

Ismail, A. (1966). Virusisolation aus den caecalen Tonsillen des Huhnes. Ing. Diss. Hannover.

Ismail A., P.E. Woalfing \& H. Gaissler (1976). Antiviral activity of some chemical disinfectants in some viral infections of poultry I. Newcastle disease virus (NDV). in preparation.

Kaleta, E.F. (1969). CELO-Virus bei Gansekuken (Kurze Mitteilung). Dtsch. tierarzfl, Wschr. 76, 427-428.

Kawamura, H., T. Sato, H. Tsubahara \& S. Isogai (1963). Isolation of CELO virus from chicken trachea. Natl. Instit. Anim. Hlth, Quart. (Tokyo) 3, 1-10.

Kawamura, H., F. Shimizu \& H. Tsubahara (1964). Avian adenovrius its properties and serological classification. Natl. Instit. Anim. Hlth. Quart. (Tokyo) 4, 183-193.

Khanna, P.N. (1964). Studies on cytopathogenic avian enteroviruses I. Their isolation and serological classification. Avian Dis. 8, 632-637.

Kohn, A (1962). Gallus adeno-like virus in chickens. Studies on infection excretion and immunity. Amer. Jour. Vet. Res. 23 : 562-567.

Krauss, H. (1965): Untersuchungen zur Charakterisierung von aus Huhneren isoliertem Orphanvirus. Arch. Exper Vet-Med. 19, 1077-1090

Monreal, G., \& A.A.S. Ahmed (1963). CELO-Virus als komplizierender Faktor bei virologischen Untersuchungen von Atems organen der Huhner, Zbl. Vet. Med B 10, 607-614.

Monreal, G (1966). Der Einfluss des CELO-Virus auf die kunstliche Infektion mit Mycoplasma gallisepticum. Berl. Munch. tierarzt1. Wschr 79, 295-297.

Monreal, G. (1968). Untersuchungen uber ein aviares Adenovirus, Habil. Schrift. Zbl. Vet. Med. B15, 685 .

Mahnel, H. (1974). Viruzide Wirkung von Desinfektionsmitteln im Suspensionsversuch. Berl. Munch. tierarztl. Wschr. 87, 385-388.

Oxfori, J.S. and C.W. Potter 1969). Chicken embryo lethal orphan (CELO) virus as possible contaminant of egg-grown virus vaccines. Jour. Hyg. (Camb). 7, 4147.

Petek, M., B. Felluga and R. Zoetto (1963 a). Biological properties of CELO-virus. 17. Vet. Congr 2, 1459-1460. Hannover.

Petek M., B. Felluga and R. Zoletto $1963 \mathrm{~b}$ ). Biological properties of CELO virus : Stability to various agents and electron microscopic study. Avian Dis 7, 38-49.

Sharpless, G.R., V. Defendi and H.R. Cox (1958) Cultivation in tissu culture of the virus of avian lymphomatozis. Proc. Soc. Exper. Biol. Med. 97, 755-757.

Sharpless, G.R., and E.I. Jungherr (1961). Characterization of two viruses obtained from lymphomatous liver. Amer. Jour. Vet. Res. 22, 937-943.

Shacpless, G.R. (1952). GAL virus. Ann. N.Y. Acad. Sci. 101, 515-519. 
Schliesser, Th. (1974 a). Zt m Problem der Stalldesinfektion. Tierarztl. prax. 2, 1-8.

Schliesser, Th. (1974b). Die Desinfektion als praventive Masșal ne tei Irffkticrikrankheiten. Fortschritte. Vet-Med. 20, 89-93.

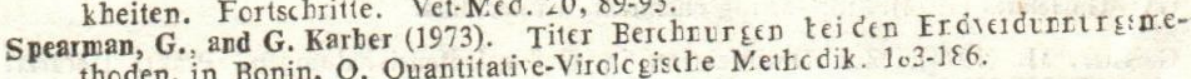
thoden, in Bonin, O. Quantitative-Virolcgiscte Netkcdik. 103-1\{6.

Woernle, H. and A. Brunner (1963). Uber cas Vesl on n.en icn CII C-Vint s-Irfekticren des Huhnes und ihre Diagnose mit Hilfe des A gar. Cell-Fraziritaticrstestces. N hft. Tierbeilk. 15, 262-270.

Yates, V.J. and D.E. Fry (1957). Observations on a chicken emryo lethal orphan (CELO) virus. Amer. Jour. Vet. Res, 18, 657-660.

Yates, V.J., P.W. Chang, A.H. Dardiri and D.E. Fry (1960). A study in the epizootiology of the BEIO virus. Avian Dis. 4, 500-505.

Assiut. Vet. Med. J. Vol. 4 No. 7 (1977). 